\title{
An investigation of workload, work-life balance, and flexible working in relation to turnover intention of Information Technology (IT) workers
}

\author{
A.S.K. Murti \& F. Martdianty \\ Master of Management, Universitas Indonesia, Indonesia
}

\begin{abstract}
The turnover rate of information technology (IT) is one the highest compared to other sectors. To minimize the turnover intention, companies need to take several factors into account, including workload, work-life balance, flexible working, and job satisfaction. The aim of this study is to analyze the relationship among workload, work-life balance, flexible working, and job satisfaction in relation to turnover intention among IT workers. This study is quantitative in nature with a cross-sectional design. Data were collected by distributing questionnaires online. The data obtained covered 272 respondents with a background as IT workers and were subsequently analyzed using the structural equation modeling method in Lisrel software. The results suggest that work-life balance and flexible working can have an indirect effect on turnover intention mediated by job satisfaction. On the other hand, workload has no indirect effect on turnover intention with the mediating effect of job satisfaction.
\end{abstract}

\section{INTRODUCTION}

The need for information technology (IT) professionals has multiplied in almost every industrial sector in Indonesia (Puslitbang-Aptika-IKP Kominfo, 2019). On the contrary, there is no corresponding growth in the supply of IT talents, as there is a deficit of workers who have IT skills (The World Bank, 2018). The supply-demand gap of IT professionals leads to staffing problems, as technology professionals are not satisfied with their current positions and likely to leave the organization to find other employment opportunities (Lo, 2015; Moore, 2000). It is in line with prior studies that have consistently pointed job satisfaction as a powerful factor that plays a significant role in regards to individual's intention to leave organizations.

As a result of the relentless technological changes in a competitive and dynamic environment, the role of IT workers, both professional and non-professional, becomes vulnerable to an increase in workload and work stress that lead to job dissatisfaction (Li \& Shani, 1991). Besides the significant effect of workload on job satisfaction, several studies have shown that there are additional factors affecting IT workers' job satisfaction, such as work-life balance and flexible working. Therefore, this study investigates whether or not workload, work-life balance, and flexible working have an indirect effect on employees' intention to leave the organization with the mediating role of job satisfaction.

\section{LITERATURE REVIEW}

Turnover intention differs from turnover in definition; turnover intention is a form of one's behavioural attitude to leave the organization, while turnover is the actual action of leaving the organization or company (Lu, Lu, Gursoy, \& Neale, 2016). Lo (2015) suggests job dissatisfaction as one of the important factors triggering someone to leave an organization, especially IT workers. Meanwhile, job satisfaction is a form of evaluation of the work they do and their response toward 
their work experiences (Berry, 1998). It leads people to compare what they feel in their organization and what other organizations offer for their position (Mobley, 1979). The balance of work and personal life is also an important issue for organizations that positively affects job satisfaction (Noor, 2011). The employees' contented state in a working environment will help them to balance between their personal and professional needs. Flexible working is defined as an organizational plan in terms of working hours and workplaces, but without the intention to reduce the working hours of individual workers (Deshwal, 2015). In addition, Allen (2001) argues that the specific benefit of flexibility can have a positive impact on job satisfaction but can also have a negative impact on turnover intention. Azar, Khan, and Eerde (2018) in their research study explain the role of job satisfaction in mediating the relationship between the use of flexible working and turnover intention. Qureshi and Khan (2011) stated that long working hours due to workload will have an opposite impact on job satisfaction. This is due to disruption of welfare in other places outside their work. The time spent by employees involves completing tasks, interests, and responsibilities at work, both directly and indirectly (Johari, Tan, \& Zulkarnain, 2018). Chung, Jung, and Sohn (2017) in their study conclude that workload is a form of work stress. This study particularly states that job stress can be related to job satisfaction, one of which is by comparing their work with other people's jobs. Job satisfaction is one of the things that is negatively related to personnel turnover or the change in personnel in an organization. Based on the explanation given above, these hypotheses are suggested:

H1: Job satisfaction mediates the effect of workload on turnover intention.

$\mathrm{H} 2$ : Job satisfaction mediates the effect of work-life balance on turnover intention.

H3: Job satisfaction mediates the effect of flexible working on turnover intention.

\section{RESEARCH METHOD}

This study is quantitative in nature, using a purposive sampling technique to test the proposed model (Figure 1). Data collection was conducted by distributing online questionnaires to a total of 272 IT workers in Indonesia. The questionnaire used in this research was adapted from previous studies concerning turnover intention (Wang, Xu, Zhang, \& Li, 2020). Job satisfaction was measured using the Minnesota Satisfaction Questionnaire (MSQ) (Weiss, Dawis, and England, 1967). Workload (Holland, Tham, \& Sheehan, 2019) and work-life balance were divided into three dimensions: work interference-personal life (WIPL), personal life_-interference work (PLIW), and work-personal life enhancement (WPLE) (Hayman, 2005). Flexible working used two main dimensions, namely, schedule flexibility and place flexibility (Pierce \& Newstrom, 1983; Katherine, Mei, Eleanor, \& Mary, 2005). All measures used a 6-point Likert scale $(6=$ strongly agree to $1=$ strongly disagree). Negatively scored items were reverse-coded for the analysis. The data were analyzed using structural equation modeling (SEM) with SPSS 22 and LISREL 8.3 software. Each hypothesis has a significant relationship if the t-value and p-value $\geq 1.96$ (Hair et al., 2014).

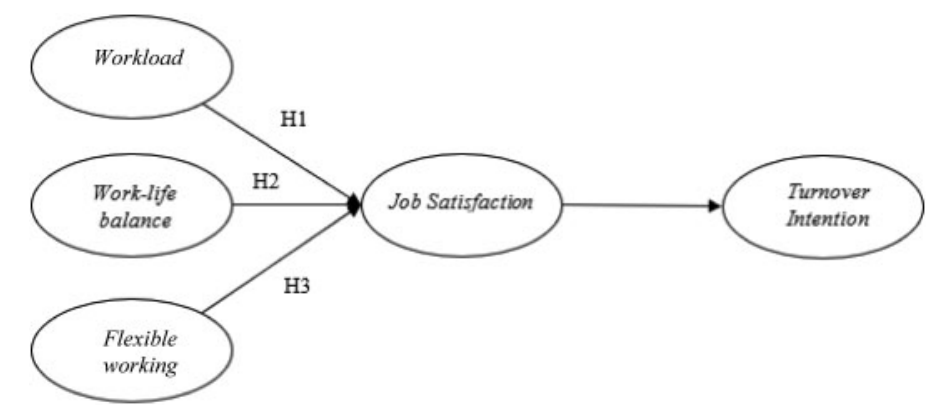

Figure 1. Research model. 


\section{RESULTS}

Based on the survey results, the demography of the respondents is as follows: $72.8 \%$ were males, $77.8 \%$ were not married, $89 \%$ were aged $21-30,81.3 \%$ had an undergraduate degree as the highest level of education, $80.5 \%$ worked as staff, and $49.3 \%$ had worked for $1-3$ years. The research model has eight good fit indexes (RMSEA, ECVI, TLI, NFI, IFI, CFI, AIC, and CAIC). Therefore, it can be concluded that the research model meets the good-fit criteria for the measured data sample.

The hypothesis testing results show that one of the three hypotheses was accepted. By testing the indirect effect using the Sobel test, one hypothesis did not fulfill the significance criteria ( $t$-value $\geq 1.96$ and $p$-value $\geq 0.05$ ) (Hair, et al., 2014). As in mediation testing, it was found that only work-life balance and flexible working have an indirect effect on turnover intention mediated by job satisfaction. Table 1 shows the results of hypothesis testing.

Table 1. Hypothesis test results

\begin{tabular}{lllll}
\hline H & Path & T-value & P-value & Evaluation \\
\hline 1 & Workload $\rightarrow$ Job Satisfaction $\rightarrow$ Turnover Intention & -1.33 & 0.182 & Not Supported \\
2 & Work-life balance $\rightarrow$ Job Satisfaction $\rightarrow$ Turnover Intention & -2.42 & 0.015 & Supported \\
3 & Flexible Working $\rightarrow$ Job Satisfaction $\rightarrow$ Turnover Intention & -2.74 & 0.006 & Supported \\
\hline
\end{tabular}

Source: Result of statistical data using LISREL

\section{DISCUSSION AND CONCLUSION}

The result of the first hypothesis test shows that job satisfaction has no mediating effect between workload and turnover intention. The respondents stated that IT workers must complete or finish their work quickly, but they were given enough time to complete the work. Despite the relatively excessive workload, they did not find it difficult or burdensome because it was compensated by the time provided by the company. In the dualistic model of the passion theory presented by Varelland et al. (2003), there is a conceptual passion analysis based on activities that are related to job demand. One type of passion is harmonious passion, which is described by workers who are passionate about their work. So they participate in their workplace more positively, and they see more control, more support, and less excessive workload. It is argued that the workload given to IT workers is not excessive, which allows them to have passion for their work, so that the perceived workload actually forms a positive outcome for the IT workers.

Job satisfaction is influenced by work-life balance, meaning that job satisfaction can negatively affect turnover intention or reduce employee turnover intention. This finding supports Noor (2011), who explained that improving the balance between life and work can lead to higher productivity and higher job satisfaction. It is important for companies to make policies or programs to minimize the existence of work that interferes with the personal life of individuals, especially in terms of the time that workers must sacrifice which can lead to disruption of workers' personal lives.

It is proven that job satisfaction is positively and significantly able to mediate the relationship between flexible working and turnover intention. The results of this study are in line with Azar, Khan, and Eerde (2018), who suggested that the use of work flexibility and the intention to leave the organization can be mediated by job satisfaction and conflict between life and work. With the company's efforts to implement work flexibility, this policy can influence a person's desire to leave the organization when that person considers the policy as a form of company concern for workers (Azar, Khan, \& Eerde, 2018). Moreover, work flexibility can contribute to workers to better adjust working hours and individual needs, and it can lead to job satisfaction of these workers (Uglanova \& Dettmers, 2013). 


\section{REFERENCES}

Azar, S., Khan, A., \& Eerde, W. V. (2018). Modelling lingkages between flexible work arrangements' use and organizational outcomes. Journal of Business Research, 91, 134-143.

Allen, T. D. (2001). Family Supportive work environments: The role of organizational perceptions.

Journal of Vocational Behaviour, 58, 414-435.

Berry, L. (1998). Psychology at Work: An Introduction to Industrial and Organizational Psychology (2nd ed.). Boston: McGraw Hill.

Chung, E. K., Jung, Y., \& Sohn, Y. W. (2017). A Moderated mediation model of job stress, job satisfaction and turnover intention for airport security screeners. Safety Science, 98, 89-97.

Deshwal, P. (2015). Impact of Flexible Working Arrangements in the MNCs of Delhi. International Journal of Applied Research, 1(13), 810-814.

Hair, J. F., Black, W. C., Babin, B. J., \& Anderson, R. E. (2014). Multivariate data analysis. Essex, UK:Pearson Education.

Hayman, J. R. (2005). Psychometric assessment of an instrument designed to measure work/life balance.

Research and Practice in Human Resource Management, 13(1), 85-92.

Holland, P., Tham, T. L., \& Sheehan, C. (2019). The Impact of Precieved Workload on Nurse Satisfaction with Work-life Balance and Intention to Leave the Occupation. Applied Nursing Research, 49, 70-76.

Johari, J., Tan, F. Y., \& Zulkarnain, Z. T. (2018). Autonomy, Workload, Work-life Balance and Job Performance Amon Teachers. International Journal of Educational Management, 32 (1).

Katherine, M. C., Mei, L., Eleanor, H. W., \& Mary, B. W. (2005). How Cirtual are we? Measuring virtuality in a Global organization. Information Systems Journal.

Li, E. Y., \& Shani, A. B. (1991). Stress dynamics of information systems managers: A Contingency Model. Journal of Management Information Systems, 12(2), 107-130.

Lo, J. (2015). The information technology workforce: A review and assessment of voluntary turnover research. Information System Frontiers, 17(1), 387-411.

Lu, L., Lu, A. C., Gursoy, D., \& Neale, N. R. (2016). Work engagement, job satisfaction and turnover intentions: a comparison between supervisors and line-level employees. International Journal of Contemporary Hospitality Management, 28(4), 737-761.

Mobley, W. H., Griffeth, R. W., Hand, H. H., \& Meglino, B. M. (1979). Review and conceptual analysis of the employee turnover process. Psychological Bulletin, 86(3), 493-522.

Noor, K. (2011). work-life balance and intention to leave among academics in Malaysian public higher education institutions. International Journal of Business and Social Science, 2(11), 240-248.

Pierce, J. L., \& Newstrom, J. W. (1983). Design of Flexible Work Schedules and Employee Responses: Relationships and Process. Journal of Occupational Behaviour, 4(4), 247-262.

Puslitbang-Aptika-IKP Kominfo. (2019). Buku Saku Kebutuhan Sumber Daya Manusia Bidang TIK Pada Sektor Usaha Besar di Indonesia Tahun 2020. Kominfo.

Qureshi, M. I., Iftikhar, M., Abbas, S. G., Hassan, U., Khan, K., \& Zaman, K. (2013). Relationship between Job Stress, Workload, Environment and Employee Turnover Intention: What we know, what should we know. World Applied Sciences Journal, 23 (6).

The World Bank. (2018). Preparing ICT Skills for Digital Economy: Indonesia within the ASEAN context. Jakarta: The World Bank Group Occupies.

Uglanova, E., \& Dettmers, J. (2013). Sustained Effects of Flexible Working Time Arrangements on Subjective Well-being. Journal of Happiness Studies, 14(4), 1-25.

Varelland, R. J., Blanchard, C. M., Mageau, G. A., Koestner, R., Ratelle, C., \& Leonard, M. (2003). Les passions de l'âme: On obsessive and harmonious passion. Journal of Personality and Social Psychology, 85(1), 756-767.

Weiss, D. J., Dawis, R. V., \& England, G. W. (1967). Manual for the Minnesota Satisfaction Questionnaire. Minnesota Studies in Vocational Rehabilitation, 22(120).

Wang, C., Xu, J., Zhang, T. C., \& Li, Q. M. (2020). Effects of professional identitity on turnover intention in China's hotel employees: The mediating role of employee engagement and job satisfaction. Journal of Hospitality and Tourism Management, 45(1), 10-22. 